\title{
Elimination of the Transient Ipsilateral Retinotectal Projection Is Not Solely Achieved by Cell Death in the Developing Chick
}

\author{
Cheri V. Williams and Steven C. McLoon \\ Department of Cell Biology and Neuroanatomy, University of Minnesota, Minneapolis, Minnesota 55455
}

During development of the projection from the retina to the brain in the chick, a transient ipsilateral retinotectal projection forms and disappears. This disappearance is coincident with a wave of ganglion cell death in the retina. The contribution of cell death to the disappearance of this projection, as opposed to another mechanism such as axon retraction, was examined. Retinal ganglion cells with a projection to the ipsilateral tectum were retrogradely labeled by injection of long-lasting fluorescent dyes into the tectum prior to the onset of ganglion cell death. Large injections of fast blue labeled approximately 1800 ganglion cells in the ipsilateral retina before the period of cell death began. If the injected embryos were allowed to survive past the peak period of ganglion cell death, the average number of labeled ganglion cells in the ipsilateral retina was reduced by somewhat more than half. It is possible that the remaining labeled ganglion cells projected only to nontectal visual nuclei and were labeled by fast blue that had diffused out of the tectum. This was tested by repeating the study using very localized injections of $1,1^{\prime}$-dioctodecyl-3,3,3',3'-tetramethylindocarbocyanine perchlorate or fluorescent microspheres into the tectum. These small injections confirmed that cells with transient projections to the ipsilateral tectum survived past the elimination of this projection. Thus, ipsilaterally projecting ganglion cells have, at most, a slightly greater propensity for death than the average ganglion cell, and elimination of the transient ipsilateral retinotectal projection in chick can be explained only, in part, by the mechanism of cell death. These data contrast with the results of similar studies in rodents, which suggest that cell death is largely, if not solely, responsible for eliminating transient retinal projections.

Considerable attention has focused on elucidating the mechanisms by which the mature pattern of neuronal connections develops. Recent work has clearly established the transient nature of certain early axonal projections (e.g., Clarke and Cowan, 1976; I and and I und, 1979; Innocenti, 1981; McLoon, 1982; O'Leary et al., 1986). These transient projections are present in the developing nervous system, but are not found in the mature system. These projections are most likely eliminated by one of

Received Apr. 3, 1990; revised Sept. 4, 1990; accepted Sept. 19, 1990.

We wish to thank Ms. Ruth Wilson for technical assistance. This work was supported by NIH Grant EYO5371 and by the Graduate School of the University of Minnesota.

Correspondence should be addressed to Steven C. McLoon, Department of Cell Biology and Neuroanatomy, University of Minnesota, 4-135 Jackson Hall, 321 Church Street SE, Minneapolis, MN 55455.

Copyright (C) 1991 Society for Neuroscience $0270-6474 / 91 / 110445-09 \$ 03.00 / 0$
2 mechanisms: the cells giving rise to these axons degenerate, or the cells withdraw these axons (Cowan et al., 1984).

The majority of transient projections studied so far suggest that axon retraction is the predominant mechanism by which these projections are eliminated. This phenomenon was first demonstrated for certain cortical neurons that exhibit a transient callosal projection early in development (Innocenti, 1981; O'Leary et al., 1981; Ivy and Killackey, 1982). These neurons retracted their callosal axons, while they maintained collaterals to other cortical regions.

An exception to the generality of axon retraction of transient projections is the climination of the transient retinotectal projection in rodents. At birth, numerous ganglion cells across the entire retina project to the ipsilateral tectum (Land and Lund, 1979). In the mature rodent, however, the major projection from the retina is to the contralateral tectum, with only a small ipsilateral retinotectal projection, primarily from the lower temporal crescent of the retina. Studies with long-lasting fluorescent dyes suggest that cells outside the lower temporal crescent of the retina with axons to the ipsilateral tectum are eliminated by cell death during the first 2 weeks of life (Cowan et al., 1984; Insausti et al., 1984). These studies and others have led to the suggestion that cell death is the means by which transient retinofugal projections are eliminated. However, these studies are difficult to interpret. The ipsilateral projection does persist in rodents, albeit in a reduced form. In these studies, we cannot distinguish between ganglion cells with a persistent ipsilateral retinotectal projection and those that survived but lost their axon to the ipsilateral tectum.

The developing chick visual system presents a number of advantages for studying this problem. In an earlier study using anterograde transport techniques, we demonstrated the presence of a transient ipsilateral retinotectal projection (McLoon and Lund, 1982). Subsequent anterograde and retrograde transport studies have confirmed and further characterized the presence of this projection (O'Leary et al., 1983; Thanos and Bonhoeffer, 1984). The ipsilateral axons first appear in the tectum on embryonic day 7 (E7), are present in peak numbers on E10, and are completely absent by E16. The mechanism by which this projection is eliminated is not known; however, cell death seemed likely. There is a massive wave of naturally occurring cell death in the retinal ganglion cell layer during chick development (Rager and Rager, 1978; Hughes and McLoon, 1979). Based on counts of axons in the optic nerve, approximately $40 \%$ of the ganglion cells degenerate (Rager and Rager, 1978). The peak period for cell death in the ganglion cell layer is from E11 to E16, the same period in which the ipsilateral projection disappears. 


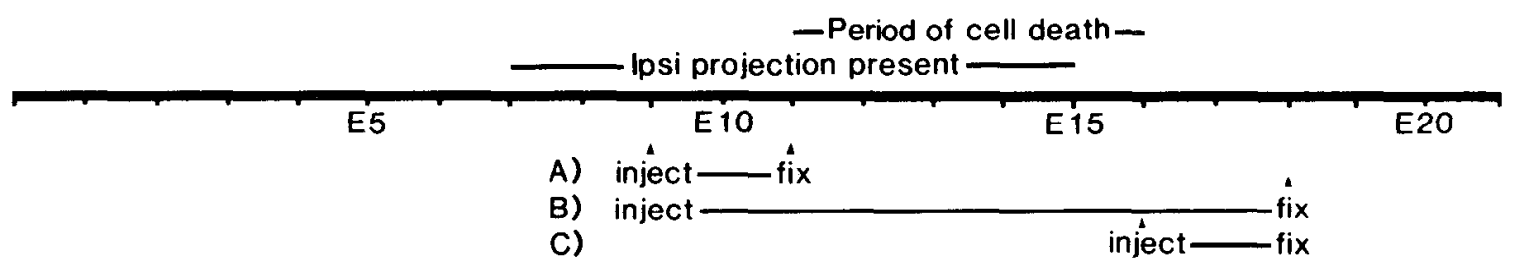

Figure 1. Timetable of experiments described. This figure graphically depicts the period of ganglion cell death and the presence of the ipsilateral retinotectal projection during embryonic development of the chick relative to the injection of fluorescent dye into the tectum and processing of the embryos in 3 of the experimental paradigms. The numbers represent days of incubation.

This study tested the hypothesis that, during the peak period of developmental cell death, the transient ipsilateral retinotectal projection is eliminated by selective death of the ganglion cells that give rise to this projection. It was found, however, that a significant proportion of ipsilaterally projecting cells did survive the period of cell death. Thus, cell death alone cannot account for the disappearance of the transient ipsilateral retinotectal projection.

\section{Materials and Methods}

Fertilized chicken eggs (pathogen-free White Leghorn crossed with Rhode Island Red) obtained from the University of Minnesota Poultry Center were incubated in an egg incubator at $37^{\circ} \mathrm{C}$. After $3 \mathrm{~d}$ of incubation, the embryos were removed from the shell and transferred to embryo culture chambers (Dunn and Boone, 1976). The cultured embryos were maintained in a forced-draft tissue culture incubator at $37^{\circ} \mathrm{C}$, with $95 \%$ relative humidity and $1 \% \mathrm{CO}_{2}$.

Five different groups of embryos received injections of retrogradely transported, long-lasting fluorescent dyes into a tectum. These dyes are taken up by the axons, are transported retrogradely to the cell body, and remain detectable within the cell body even after long postinjection survival times (Bentivoglio et al., 1980; Katz et al., 1984; Thanos and Bonhoeffer, 1987). The first 3 groups received multiple injections of fast blue in the right tectum in an effort to retrogradely label all the ganglion cells projecting to that tectum.

The first group received fast blue injections into the right tectum on E9. This corresponds to the time when most retinal axons have entered the tectum. The retinas and brains were removed and processed for histological examination when the ipsilateral projection is at a peak, between $\mathrm{E} 11$ and $\mathrm{E} 12$.

The second group also received fast blue injections on E9, but these embryos were processed on E18, well after the disappearance of the ipsilateral projection.

The third group received fast blue injections on E16 and was processed on E18. This was done to verify the absence of the ipsilateral projection after the period of naturally occurring cell death. The protocol for these 3 groups in relation to certain developmental events is summarized in Figure 1.

The large injections used in the first 3 experimental groups often spread into visual nuclei other than the tectum. Thus, it is possibie that some of the ipsilateral ganglion cells labeled in this procedure projected to these other visual nuclei. Some of these other nuclei are known to receive ipsilateral retinal projections after development is complete (O'Leary et al., 1983). For this reason, a fourth group of embryos received single small injections of $1,1^{\prime}$-dioctodecyl-3,3,3',3'-tetramethylindocarbocyanine pcrchloratc (DiI; Thanos and Bonhoeffer, 1987) or fluorescently labeled latex microspheres (Katz et al., 1984) into the right tectum on E9 and was processed on E11 or E18. In contrast to fast blue, DiI and the fluorescently labeled latex microspheres provided very localized dye injections with virtually no spread of dye into nontectal visual nuclei. This was done in an effort to definitely identify ganglion cells projecting to the ipsilateral tectum. However, this method by no means labels all the ipsilateral ganglion cells projecting to a tectum in an individual animal and is therefore not a reliable method for quantifying the amount of cell death.

The fifth group of embryos, a control group, received large fast blue injections into the forebrain on E9 and was processed on E11 or E18. This controlled for nonspecific labeling of ganglion cells and for labeling of ganglion cells via the ventricular system.
A $2 \%$ suspension of fast blue (Sigma) in saline was injected into the embryos via a pulled glass pipette attached to an oil-filled Hamilton syringe. Latex microspheres in a dilution as supplied by the distributor (LumaFluor Inc.) were injected with a similar apparatus. Crystals of DiI (Molecular Probes) were inserted into the tectum through the skin via a sharpened sewing needle dipped in dye. The first 3 groups of embryos received multiple injections of fast blue along the rostroinferior margin of the right tectum (Fig. 2). It is in this region that the retinal axons enter the tectum from the optic tract (Goldberg, 1974; McLoon, 1985) Injections were made tangentially along this border to ensure that the maximum number of retinal axons entering the tectum would be labeled. A total of between 0.5 and $1.0 \mu \mathrm{l}$ fast blue was injected into each embryo. (The amount of dye injected does not reflect the actual amount delivered to the tectum, because some dye escaped into the amniotic cavity along the injection tract.) The fourth group of embryos received a single small injection of a dye slightly above the rostroinferior margin of the right tectum. Approximately $0.25 \mu \mathrm{l}$ of the latex microspheres was injected in each embryo or a single stab of a needle dipped in DiI. Control embryos, group 5, received a 1.0-2.0 $\mu 1$ injection of fast blue into the right forebrain.

Retinal whole-mounts were prepared from these embryos by first removing the eyes to phosphate buffer $(\mathrm{pH}, 7.4)$. The retinas were then dissected from the eyes and placed in $4 \%$ paraformaldehyde in phosphate buffer. After $1 \mathrm{hr}$ of fixation, the retinas were mounted whole onto glass slides and coverslipped in an aqueous mounting media. The retinas were examined with a microscope equipped for epifluorescence with a 100-W mercury bulb and filters appropriate for the particular tracers used.

The distribution of labeled cells in the ganglion cell layer of retinal whole-mounts was plotted onto enlarged tracings of the retinas (e.g., Fig. 3). This was accomplished by means of an $x-y$ plotter interfaced with the stage of the microscope. The position of the microscope stage relative to the cross hairs in the oculars was indicated by the position of the plotter pen. Retinas contralateral to the injected tecta were analyzed to determine the extent of the dye injections. Retinas ipsilateral to the injected tecta were analyzed to determine the total number and distribution of labeled cells. The density of cells was calculated in the central retina, a $3-\mathrm{mm}$ circle (real retina size) just above the optic fissure, and in each peripheral retinal quadrant. Areas for the density calculations were measured with a Bioquant Image Analysis System. All numbers presented in the Results represent the mean of counts from at least 8 retinas. Standard deviations were calculated for all means.

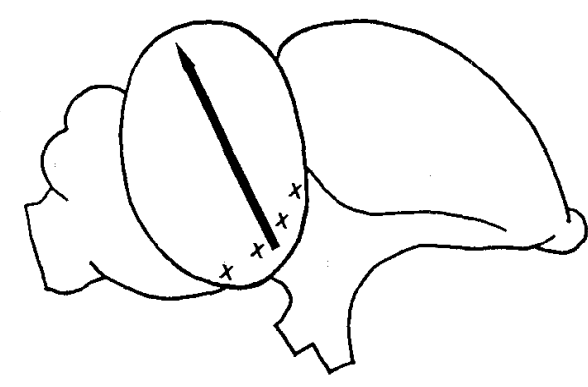

Figure 2. Diagram of E9 chick brain. The approximate position of the fluorescent dye injections $(X S)$ and the direction of ingrowth of the optic axons (arrow) are indicated. 

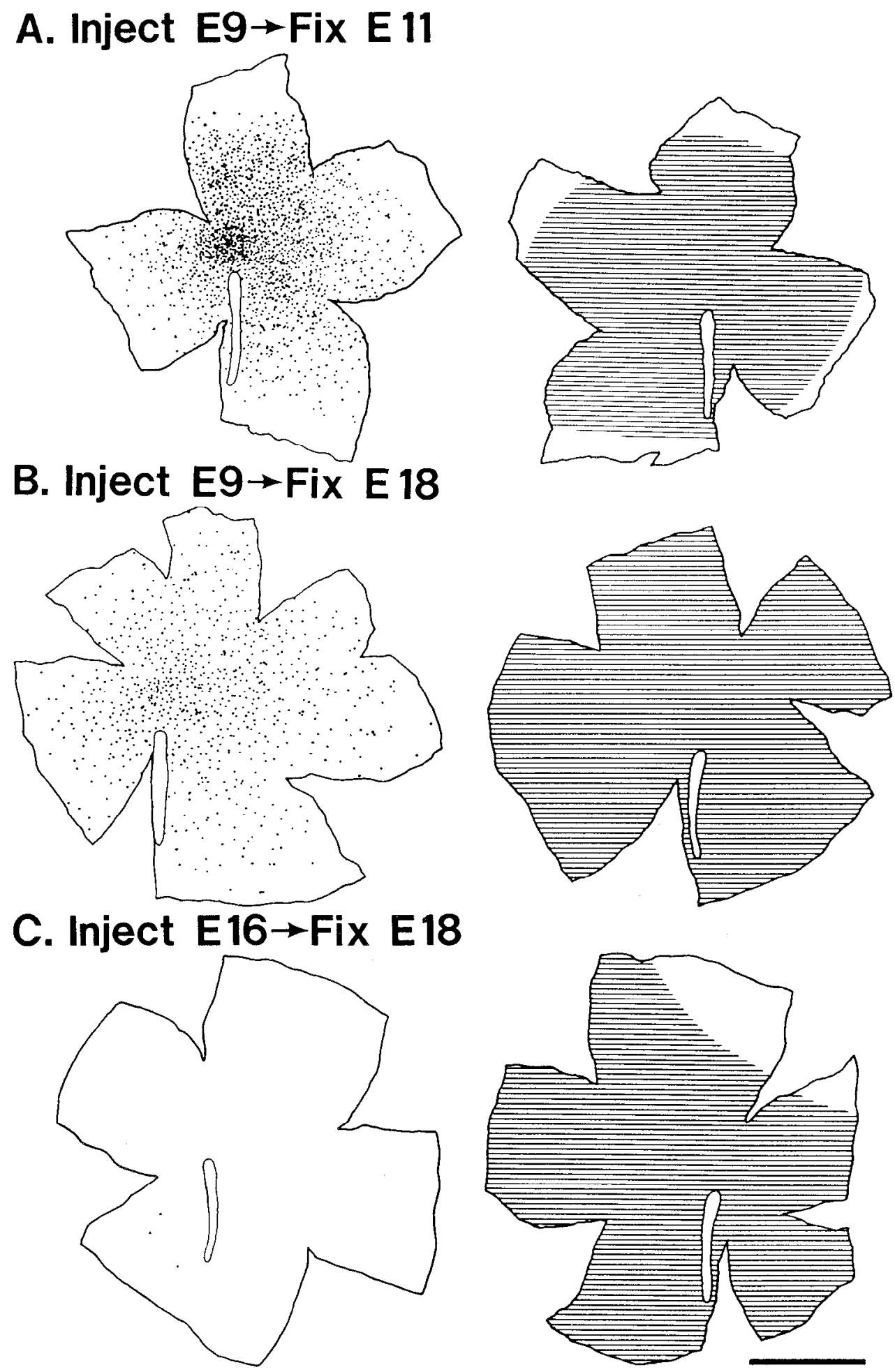

Figure 3. Plots of retinal wholemounts from 3 embryos. The retinas on the left are ipsilateral to a tectum injected with fast blue. The dots indicate fast-blue-labeled cells in the ganglion cell layer. The retinas on the right are contralateral to an injected tectum. The shaded areas represent areas with a high concentration of labeled cells. $A$, Retinas from an embryo injected on E9 and fixed on E11. B, Retinas from an embryo injected on E9 and fixed on E18. $C$, Retinas from an embryo injected on E16 and fixed on E18. Scale bar, $5 \mathrm{~mm}$.

Four retinal whole-mounts ipsilateral to a tecta injected with fast blue from group 2 embryos were removed from the slides and sectioned. The retinas were sectioned frozen at $8 \mu \mathrm{m}$. Sections were mounted on glass slides and counterstained with acridine orange (Schmued et al., 1982). Fast-blue-labeled cells were located in the sections. Then, the microscope filters were switched to reveal the acridine-orange-stained cells. Acridine orange stains all of the cells in the retina. In this way, it was determined whether or not the fast-blue-labeled cells were in the ganglion cell layer.
To determine the extent of the fluorescently labeled injections in the brain, all injected embryos were perfused through the heart with $4 \%$ paraformaldehyde in phosphate buffer after the removal of their eyes. The brains of the embryos were sectioned frozen, and the sections were mounted in serial order onto glass slides. These were also examined with a fluorescence microscope. Only embryos in which the injection was confined to one side of the brain were used in this study (except for group 5 embryos, in which laterality was not important). A total of over 150 embryos were analyzed in this study. 

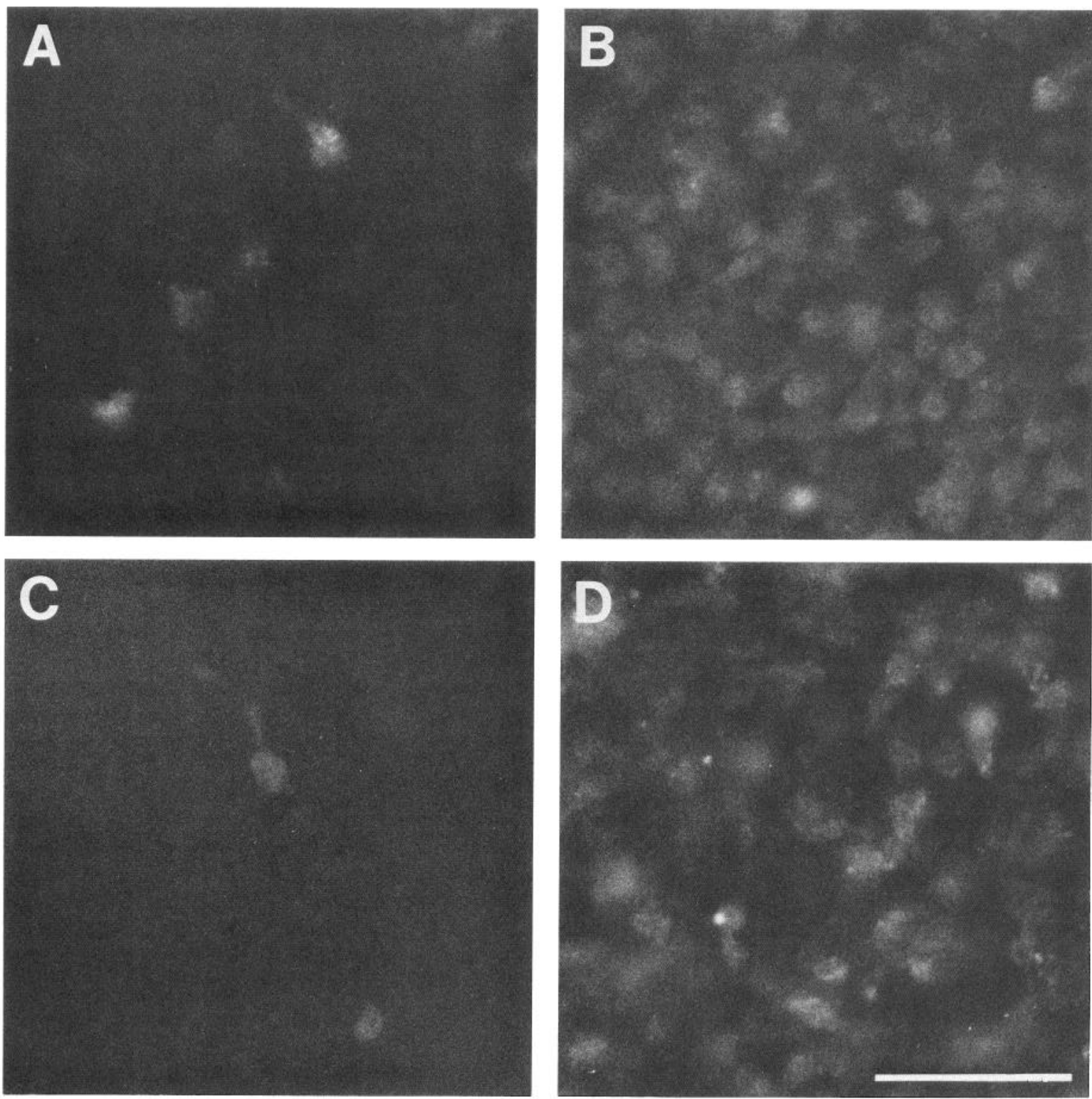

Figure 4. Photomicrographs of cells labeled with fast blue in the center of retinal whole-mounts. The photomicrographs on the left are ipsilateral to an injected tectum, and those on the right are contralateral. $A$ and $B$ are from an embryo injected on E9 and fixed on E11. $C$ and $D$ are from an embryo injected on E9 and fixed on E18. Scale bar, $50 \mu \mathrm{m}$.

\section{Results}

Fluorescent labels (fast blue, DiI, or fluorescently labeled latex microspheres) injected into the optic tecta retrogradely labeled ganglion cells in both retinas. The number and pattern of labeled cells varied with the different paradigms. The data for each of 5 experimental groups are presented separately.

\section{Group 1}

Embryos that were injected on E9 and fixed on E11 had a high density of labeled cells in the ganglion cell layer of the retina contralateral to the injected tectum (Figs. $3 A, 4 B$ ). Very few labeled cells were present in the most peripheral areas of the retina in these embryos. By E12, the high density of labeled cells covered the entire retina. In a few cases, the labeling was incomplete in some regions of the retina. Only animals with labeled ganglion cells across the entire retina were included in the analysis of the ipsilaterally projecting ganglion cells.

Embryos that were injected on E9 and fixed on E11 had an average of $1550 \pm 136$ fast-blue-labeled cells in the ganglion cell layer of the ipsilateral retina (Figs. $3 A, 4 A$ ). There was a marked central-to-peripheral gradient in the number of ipsilaterally projecting ganglion cells across the retina, with the highest concentration in central retina and lowest in peripheral retina (Table 1). If the embryos were fixed $1 \mathrm{~d}$ later (E12), there was an increase in the number of ipsilaterally labeled cells in the peripheral retina (primarily in the superior-nasal retina) by about 250 cells, but there was a decrease in the central retina. Taking into account these additional peripheral cells, approximately 1800 cells in the ganglion cell layer of a retina project to the ipsilateral tectum prior to the period of ganglion cell death.

Based on the plane of focus, displaced ganglion cells in the 

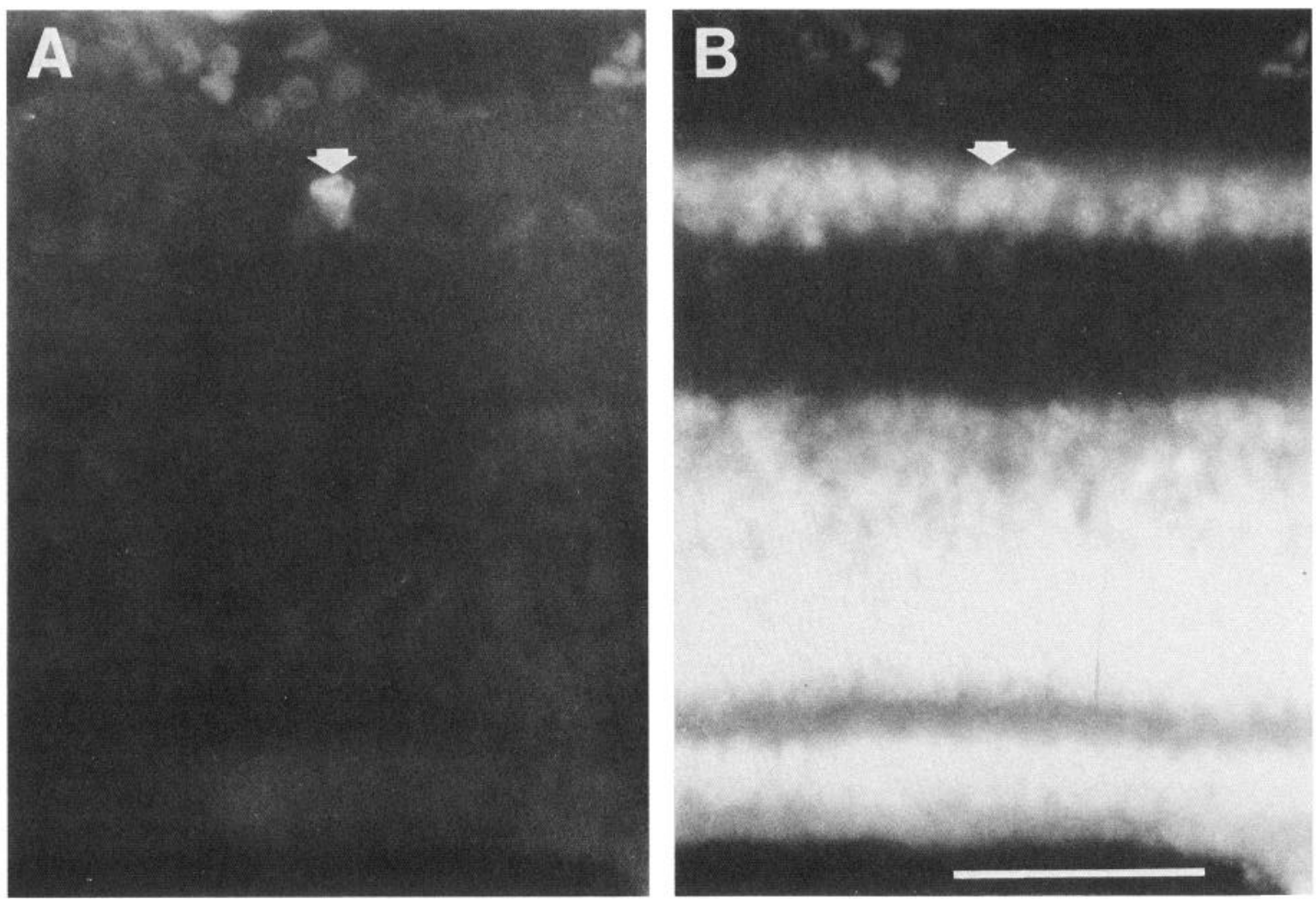

Figure 5. Photomicrographs of labeled cells in the ganglion cell layer (arrows) of E18 retina. $A$, Photomicrograph of a fast-blue-labeled cell in the ganglion cell layer from a sectioned E18 retina. The tectum ipsilateral to this retina was injected on E9. $B$, The same field as in $A$ photographed with different filters to reveal all the retinal cells stained with acridine orange. Scale bar, $50 \mu \mathrm{m}$.

ipsilateral and contralateral retinas were also labeled by these injections. Displaced ganglion cells in the mature visual system are known to project to nontectal visual nuclei (Karten et al., 1977). As was evident from the brain sections of these embryos, the dyes had spread from the tectum into other visual nuclei. This most likely accounts for the labeling of the displaced ganglion cells. Because of the substantial variation in the number of displaced ganglion cells labeled, they were not included in any counts of ipsilaterally projecting ganglion cells.

Brain sections of these embryos allowed easy identification of the dye injection sites. All embryos used in the analysis had injection sites along the rostroinferior margin of the tectum. The highest concentration of the dye was in the area around the injection sites, and it gradually declined away from the injection sites. In all brains, there was a high level of dye in the visual nuclei rostral to the tectum. Although it is not possible to identify the effective dye uptake area histologically, it seems likely that some of the ganglion cells labeled by these injections terminated in regions outside the tectum.

\section{Group 2}

Embryos that were injected on E9 and allowed to survive until E18 had a high density of labeled cells across the entire retina contralateral to the injected tectum (Figs. $3 B, 4 D$ ). Again, any embryos showing inconsistencies in this labeling were excluded from the analysis of the ipsilateral projection.

Embryos injected on E9 and fixed on E18 had an average of $725 \pm 107$ labeled cells remaining in the ipsilateral retina (Figs. $3 B, 4 C$ ). Sections of these retinas confirmed that the remaining labeled cells were in the ganglion cell layer (Fig. 5). A comparison of the change in density of labeled cells between E11-12 and E18 in individual regions of the ipsilateral retinas showed that all retinal areas had a similar change in density (Table 1). This suggests that the percent of ipsilaterally projecting cells that degenerate is relatively uniform across the retina.

The brain sections of these embryos were effectively identical to that of group 1 .

Table 1. Fast-blue-labeled cells in the retina ipsilateral to an injected tectum

\begin{tabular}{|c|c|c|c|c|c|c|c|}
\hline \multirow{2}{*}{$\begin{array}{l}\text { Age } \\
\text { injected }\end{array}$} & \multirow{2}{*}{$\begin{array}{l}\text { Age } \\
\text { fixed }\end{array}$} & \multirow[b]{2}{*}{ Total $^{a}$} & \multirow{2}{*}{$\begin{array}{l}\text { Cen- } \\
\text { tral } \\
\text { retina }^{b}\end{array}$} & \multicolumn{4}{|c|}{ Peripheral retina $^{b}$} \\
\hline & & & & SN & IN & ST & IT \\
\hline \multicolumn{8}{|c|}{ Tectal injections } \\
\hline E9 & E11 & $1550 \pm 136$ & 43 & 10 & 9 & 10 & 8 \\
\hline E9 & E12 & $1738 \pm 211$ & 38 & 11 & 10 & 10 & 9 \\
\hline E9 & E18 & $725 \pm 107$ & 15 & 4 & 3 & 3 & 3 \\
\hline E16 & E18 & $2 \pm 1$ & 0 & 0 & 0 & 0 & $0^{c}$ \\
\hline
\end{tabular}

Forebrain injections
E9
E12
0
0
$\begin{array}{llll}0 & 0 & 0 & 0\end{array}$

${ }^{a}$ Mean number of cells \pm SD from at least 8 retinas.

${ }^{b}$ Mean number of cells per $\mathrm{mm}^{2}$. For the sake of readability, SDs are not shown, but are always less than $20 \%$ of the number. Data are shown for the superiornasal (SN), inferior-nasal (IN), superior-temporal (ST), and inferior-temporal (IT) retinal quadrants.

c The inferior-temporal quadrant contained the labeled cells in some of these embryos. However, their density was too low to be reflected in this number. 


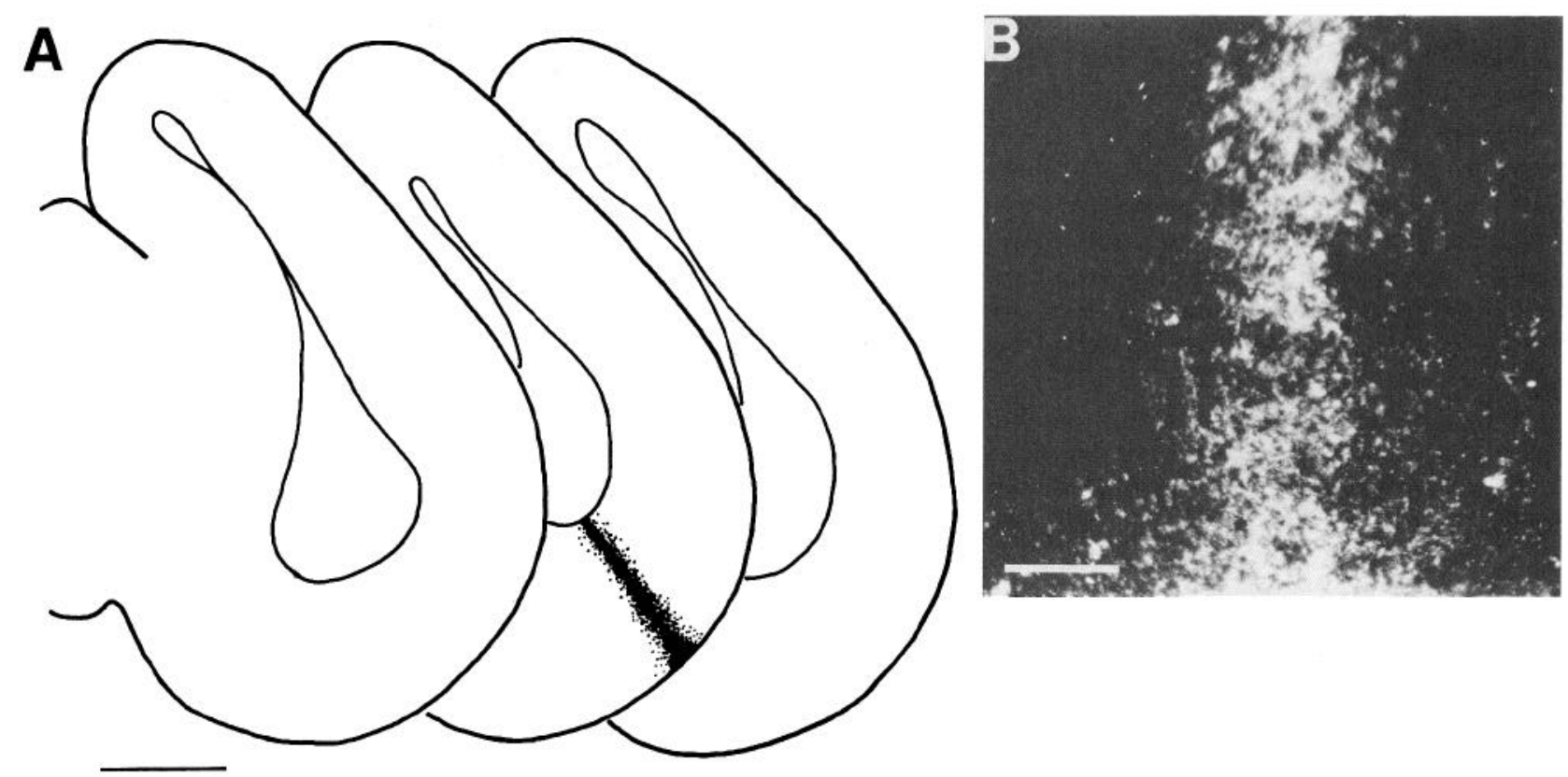

Figure 6. A, Camera lucida drawing of 3 serial sections through a tectum injected with microspheres. The embryo was injected on E9 and fixed on E18. The 3 sections represent approximately $100-\mu \mathrm{m}$ intervals. The injection site is present in the middle section. No microspheres were present in sections $100 \mu \mathrm{m}$ to either side of the injection site. Scale bar, $1 \mathrm{~mm}$. B, A fluorescence micrograph of the injection site. Scale bar, $100 \mu \mathrm{m}$.

\section{Group 3}

Embryos injected on E16 and fixed on E18 did not show labeling of cells across the entire retina contralateral to the injected tectum. Examination of the brain sections revealed only partial filling of the tecta by the fast blue injections. We never succeeded in making large enough dye injections to label the entire contralateral retina in a single embryo. These injections resulted in a variable number of labeled cells in the ipsilateral retina. Only when the contralateral retina was labeled in the lower temporal quadrant were labeled cells found in the ipsilateral retina. When the contralateral lower temporal retina was labeled, between 0 and 8 fast-blue-labeled cells were found in the ipsilateral retina, with a mean of $2 \pm 1$ cells (Fig. $3 C$ ). These cells were always located in lower temporal retina.

\section{Group 4}

Ipsilateral retinofugal projections to nontectal visual nuclei are believed to persist in the mature chick (O'Leary et al., 1983). Because the large fast blue injections, particularly in groups 1 and 2 above, spread into nontectal visual nuclei, it seemed possible that the ipsilaterally projecting ganglion cells that survived the period of cell death may never have had axons that reached the ipsilateral tectum. To eliminate the possibility that the remaining labeled ipsilateral cells were actually cells with axons that projected to nontectal visual nuclei, it was necessary to make smaller dye injections that remained entirely restricted to the tectum, in order to label only ganglion cells with axons in the tectum. Fast blue was not particularly suited for this because of its considerable spread away from the area of the injection. After testing a number of retrograde tracers, DiI and latex microspheres were found to remain much more restricted to the area of the injection.

Small, single DiI or latex microsphere injections were made into the tectum of E9 embryos. These embryos were processed on E11 or E18. Examination of the brain sections confirmed that these injections were confined to the tectum (Fig. 6). There were many labeled cells in a localized region of the contralateral retina corresponding topographically to the injection site (Crossland et al., 1974). Also, there were no displaced ganglion cells labeled in the retinas of these embryos. A confined area of the ipsilateral retina in each embryo had a small population of labeled cells (Figs. 7, 8), in retinas examined from both E1 1 and E18 embryos. However, the number of ipsilaterally labeled cells varied considerably from embryo to embryo. For this reason, a quantitative analysis of the number of ipsilaterally labeled cells at E11 and E18 was not meaningful. Most importantly, ipsilaterally labeled ganglion cells were consistently seen in E18 embryos, after the main period of cell death and after the elimination of the ipsilateral retinotectal projection. This clearly shows that a significant population of ganglion cells that project to the ipsilateral tectum early in development do not die by the time the ipsilateral projection has disappeared.

\section{Group 5}

Most embryos that received fast blue injections into the tectum had some fluorescence within the ventricles. This was often present on both sides. To determine whether the presence of fast blue within the ventricles could lead to ganglion cell labeling, large fast blue injections were made into the forebrain of a separate group of embryos. This resulted in considerable fluorescence along the entire ventricular system, including that of the tectum. In no case did the forebrain injections result in labeled ganglion cells. This group also served as a control for blood-borne dye transfer and any other nonspecific labeling of the ganglion cells.

\section{Discussion}

This study showed that approximately 1800 ganglion cells in a retina projected to the ipsilateral side of the brain prior to the period of ganglion cell death. This was based on retrograde 


\section{A. Inject E9 $\rightarrow$ Fix E 11}

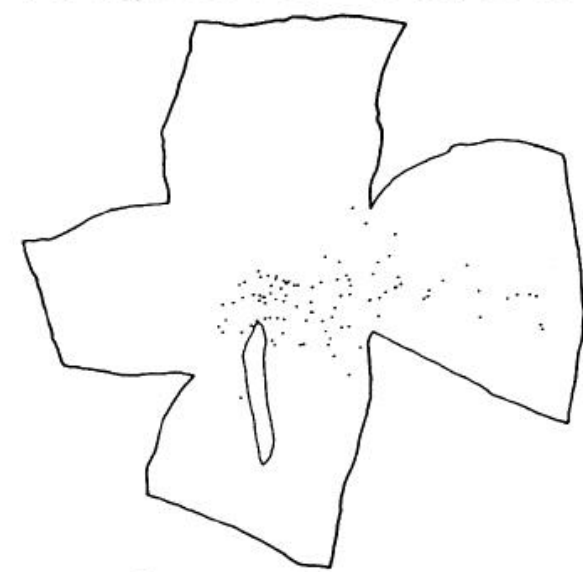

B. Inject E9 $\rightarrow$ Fix E 18

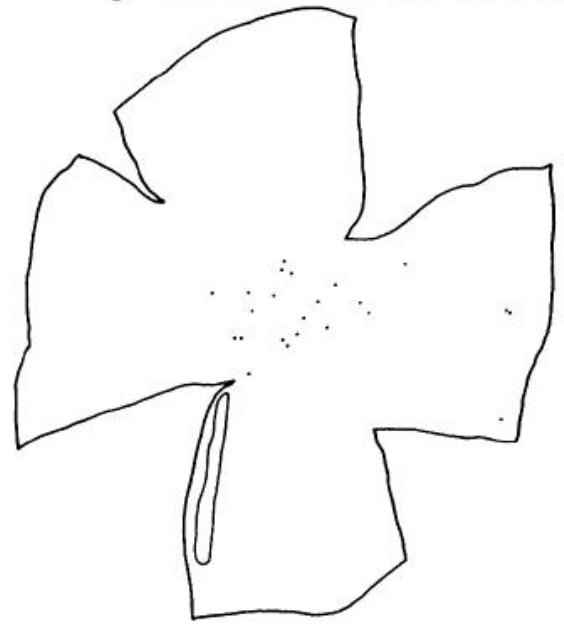

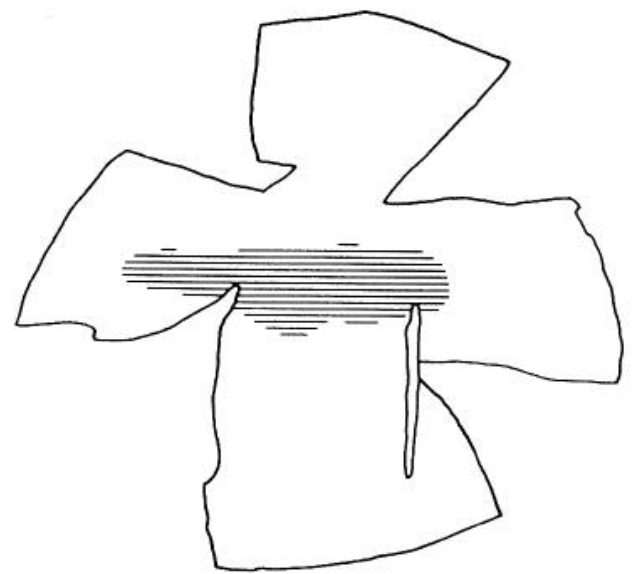

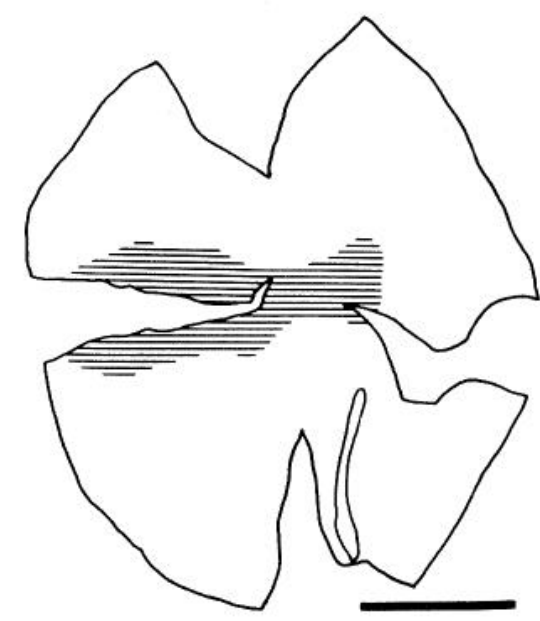

Figure 7. Plots of retinal whole-mounts from 2 embryos. The retinas on the left are ipsilateral to a tectum injected with latex microspheres. The dots indicate latex-microsphere-labeled cells in the ganglion cell layer. The retinas on the right are contralateral to an injected tectum. The shaded areas represent areas with the highest concentration of labeled cells. $A$, Retinas from an embryro injected on E9 and fixed on E11. $B$, Retinas from an embryo injected on E9 and fixed on E18. Scale bar, $5 \mathrm{~mm}$. labeling of ganglion cells by large injections of fast blue into a tectum. Because of the retrograde labeling technique used, it is likely that this number includes ganglion cells that do not project to the tectum, but rather to other visual nuclei known to receive a projection from the ipsilateral retina (O'Leary et al., 1983; Weidner et al., 1985). Small tracer injections confined to the tectum labeled approximately $8 \%$ fewer cells in a given region of the ipsilateral retina than did large injections (S. C. McLoon, unpublished observations). This suggests that at least $92 \%$ of the 1800 ipsilaterally projecting ganglion cells do project to the tectum. This number of ipsilaterally projecting cells is somewhat less than that obtained using an anterograde labeling technique. Eye injections of rhodamine isothiocyanate labeled approximately 2000 axons in the ipsilateral tectum at this stage of development (Thanos and Bonhoeffer, 1984). It would be expected that anterograde labeling with intraocular injections is more efficient than retrograde labeling with injections into the target field.

Approximately 725 of the ganglion cells in a retina that initially projected ipsilaterally survived the peak period of cell death. This was determined by retrogradely labeling the ipsilaterally projecting ganglion cells prior to the period of cell death with injections of fast blue into the tectum. These embryos were then allowed to survive until after the period of cell death, at which time the surviving labeled cells in these retinas were

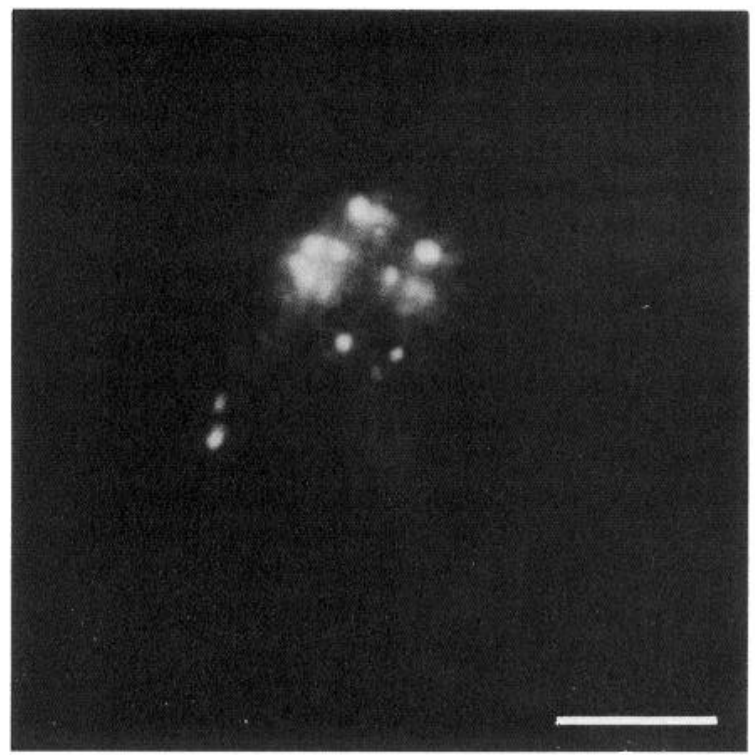

Figure 8. Photomicrograph of a cell ipsilateral to an injected tectum, labeled with latex microspheres in the center of retinal whole-mounts. Scale bar, $10 \mu \mathrm{m}$. 
counted. It is unlikely that the labeled cells that remained were the result of a secondary transfer of dye between cells in the retina. Dye spilled from a degenerating cell would most likely be taken up by several cells in the area. Our labeled cells were almost always alone. Also, the dye was confined to large cells of the ganglion cell layer, a characteristic that would suggest they are ganglion cells. Spilled dye would be taken up by glial cells of the optic fiber layer or Müller cells, which span all retinal layers; neither of these were observed. It is possible that the ipsilaterally projecting ganglion cells labeled by early injections of fast blue into the tectum were labeled by dye that had spread outside the tectum. Thus, those labeled cells that survived the period of cell death may represent cells that never projected to the tectum, but rather, had sustained projections to other nontectal visual nuclei (O'Leary et al., 1983). This is unlikely because only about $8 \%$ of the 1800 cells labeled by large tracer injections into the ipsilateral tectum prior to the period of cell death projected to nontectal nuclei. Even if all $8 \%$ survived, which is unlikely, they could not account for the 725 labeled cells remaining. Furthermore, this possibility is ruled out by the small injections of DiI or microspheres that were confined to the tectum. These small injections definitively showed that at least some ganglion cells with early ipsilateral retinotectal projections survived the period of cell death.

Based on counts of axons in the optic nerve at different ages of development, approximately $40 \%$ of all ganglion cells degenerate during the peak period of cell death in the ganglion cell layer (Rager and Rager, 1977). Comparison of the counts before and after the period of cell death suggests that about $60 \%$ of the ipsilaterally projecting ganglion cells degenerated during this time. Because of variability in labeling, it would not be wise to take this number too literally, but it appears that ipsilaterally projccting ganglion cclls have, at most, a slightly grcater propensity for death than the average ganglion cell.

The results presented here, as well as those of others (McLoon and Lund, 1982; O'Leary et al., 1983; Thanos and Bonhoeffer, 1984), show that the ipsilateral retinotectal projection is virtually eliminated by E18. Anterograde labeling studies did not identify even a few axons in the tectum from the ipsilateral retina. However, a few labeled axons could easily have been overlooked. In the present study, only a few ipsilaterally projecting ganglion cells were retrogradely labeled late in development, and it is not completely clear that these were labeled from the tectum. Dye from these injections had also spread into nontectal visual nuclei, which may have been the source of label for these cells. Because many of the ganglion cells that had axons projecting to the ipsilateral tectum early in development survived past the elimination of this projection, it can be concluded that ganglion cell death in the chick is not solely responsible for the elimination of the ipsilateral retinotectal projection.

There are 5 possible mechanisms for the apparent elimination of the ipsilateral retinotectal projection from ganglion cells that survived the major wave of cell death in the chick. First, cells could lose ipsilaterally projecting axon collaterals while retaining contralateral branches. Such a phenomenon has been described with regard to the laterality of the projection of certain cortical cells in mammals (Innocenti, 1981; O'Leary et al., 1981; Ivy and Killackey, 1982). However, this seems unlikely to be the case in the present study, because ganglion cells in the chick retina could not be double labeled by injections of tracers into each tectum early in development (Thanos and Bonhoeffer, 1984). Second, cells could retract their ipsilaterally projecting axons to the chiasm and regrow them into the contralateral side. Recent studies of the chick visual system suggest that retinal axons are capable of making changes in their site of termination within the tectum during development (Nakamura and O'Leary, 1989). A number of retinal axons were seen to grow over the contralateral tectum to topographically incorrect positions, and then, secondarily, turn or put out collaterals to the correct region of the tectum. A similar but more dramatic rearrangement of projections could account for the loss of the chick ipsilateral retinotectal projection. However, it would require retraction and growth of several millimeters at a time in which few axonal growth cones are found in the optic tract (McLoon, unpublished observations). Third, cells could withdraw their axons from the ipsilateral tectum and maintain collaterals or form new connections with other visual nuclei on the ipsilateral side of the brain. Ipsilateral retinofugal projections persist in the adult to certain visual nuclei, primarily the ectomamillary nucleus and nucleus externus (O'Leary et al., 1983; Weidner et al., 1985). Fourth, cells could lose their axons and become amacrine cells. There is some evidence for ganglion cells converting to amacrine cells in the developing mammalian retina (Hinds and Hinds, 1983), though this is still in debate (Perry et al., 1983). Fifth, cells could stop transporting tracer substances and degenerate over a longer period than the main wave of cell death. Some cells undergoing degeneration are encountered in the ganglion cell layer past E16 (Hughes and McLoon, 1979). Also, in the developing mammalian visual system, degenerating optic axons have been observed after the peak period of ganglion cell death (Williams et al., 1986). Further studies are required to evaluate these possibilities completely.

It is interesting that the method for elimination of the ipsilateral retinotectal projection in the chick differs from the elimination of the ipsilateral isthmoretinal projection in the same species. There is a projection from the isthmo-optic nucleus to the ipsilateral retina that also mostly disappears during chick development (Clarke and Cowan, 1976). Unlike the ipsilateral retinotectal projection, this projection appears to be eliminated by the death of the neurons that give rise to the projection (O'Leary and Cowan, 1982).

The development and elimination of the transient ipsilateral retinotectal projection in the chick contrasts in several ways with that of the rat and hamster. In the chick, there is a graded central-to-peripheral distribution of ipsilaterally projecting ganglion cells, with the highest density in the central retina and the lowest in the peripheral retina. Also, the number of ganglion cells that project to the ipsilateral tectum from any given region of the retina is proportional to all cells in the ganglion cell layer of that region (as suggested by comparison of the data from this study to that of Ehrlich, 1981). In the rat and hamster, however, the highest density of ipsilaterally projecting cells is in the peripheral margin of the lower temporal retina, and the majority of ganglion cells in this region project to the ipsilateral side of the brain (Cowan et al., 1984; Insausti et al., 1984; Sretavan, 1990). A more significant difference between these species appears to be in the mechanism by which the transient ipsilateral retinotectal projection is eliminated during development. Although there is a significant projection from the lower temporal retina to the rostromedial portion of the ipsilateral superior colliculus in the mature rat and hamster, during development this projection arises from much of the retina and covers most of the ipsilateral colliculus (Frost et al., 1979; Land and Lund, 1979). Long-lasting fluorescent dye studies suggest that cells 
giving rise to the expanded portion of this projection selectively degenerate during the period of ganglion cell death (Cowan et al., 1984; Insausti et al., 1984). Thus, cell death appears to be the mechanism by which the expanded ipsilateral projection is eliminated in rats and hamsters. However, interpretation of the results in rodents is clouded by the presence of some cells in all areas of the mature retina with persistent projections to the ipsilateral tectum.

The factors initiating the elimination of the ipsilateral projections may also differ between rodents and chicks. Competition appears to play an important role in the rat and hamster. If one eye is removed at birth, the expanded ipsilateral projection persists to maturity (Finlay et al., 1979; Land and Lund, 1979; Thompson, 1979), and the death of the cells giving rise to this projection is almost completely prevented (Cowan et al., 1984; Insausti et al., 1984). In the chick, removal of one eye very carly in development results in an cven larger ipsilateral retinotectal projection than found in the normal embryo (Raffin and Reperant, 1975; Thanos et al., 1984). However, it is still completely eliminated during subsequent development (Thanos et al., 1984).

In summary, this study has 2 main conclusions. First, somewhat more than half of the ganglion cells giving rise to the ipsilateral relinotectal projection are lost during the period of developmental ganglion cell death. This suggests, at most, a slight predisposition for these cells to degenerate as compared to the entire ganglion cell population. Second, cell death alone cannot account for the disappearance of the ipsilateral retinotectal projection. It seems likely that some cells must withdraw their axons from the ipsilateral tectum in favor of some other termination site.

\section{References}

Bentivoglio M, Kuypers HGJM, Catsman-Berrevoets CE, Loewe $\mathbf{H}$, Dann O (1980) Two new fluorescent retrograde neuronal tracers which are transported over long distances. Neurosci Lett 18:25-30.

Clarke PGH, Cowan WM (1976) The development of the isthmooptic tract in the chick, with special reference to the occurrence and correction of developmental errors in the location and connections of isthmo-optic neurons. J Comp Neurol 167:143-164.

Cowan WM, Fawcett JW, O'Leary DDM, Stanfield BB (1984) Regressive events in neurogenesis. Science 225:1258-1265.

Crossland WJ, Cowan WM, Rogers LA, Kelly JP (1974) The specification of the retino-tectal projection in the chick. J Comp Neurol 155:127-164.

Dunn BE, Boone MA (1976) Growth of the chick embryo in vitro. Poult Sci 55:1067-1071.

Ehrlich D (1981) Regional specialization of the chick retina as revealed by the size and density of neurons in the ganglion cell layer. J Comp Neurol 195:643-657.

Finlay BL, Wilson KG, Schneider GE (1979) Anomalous ipsilateral retinotectal projections in Syrian hamsters with early lesions: topography and functional capacity. J Comp Neurol 183:721-740.

Frost DO, So K-F, Schneider GE (1979) Postnatal development of retinal projections in Syrian hamsters: a study using autoradiographic and anterograde degeneration techniques. Neuroscience 4:1649-1677.

Goldberg S (1974) Studies on the mechanics of development of the visual pathways in the chick embryo. Dev Biol 36:24-43.

Hinds JW, Hinds PL (1983) Development of retinal amacrine cells in the mouse embryo: evidence for two modes of formation. J Comp Neurol 213:1-23.

Hughes WF, McLoon SC (1979) Ganglion ccll dcath during normal retinal development in the chick: comparisons with cell death induced by early target field destruction. Exp Neurol 66:587-601.
Innocenti GM (1981) Growth and reshaping of axons in the establishment of visual callosal connections. Science 212:824-827.

Insausti R, Blakemore C, Cowan WM (1984) Ganglion cell death during development of ipsilateral retino-collicular projection in golden hamster. Nature 308:362-365.

Ivy GO, Killackey HP (1982) Ontogenetic changes in the projections of neocortical neurons. J Neurosci 2:735-743.

Karten HJ, Fite KV, Brecha N (1977) Specific projection of displaced retinal ganglion cells upon the accessory optic system in the pigeon. Proc Natl Acad Sci USA 74:1153-1756.

Katz LC, Burkhalter A, Dreyer WD (1984) Fluorescent latex microspheres as a retrograde neuronal marker for in vivo and in vitro studies of visual cortex. Nature 310:498-500.

Land PW, Lund RD (1979) Development of the rat's uncrossed retinotcetal pathway and its relation to plasticity studics. Scicnec 205: 698-700.

McLoon SC (1982) Alterations in precision of the crossed retinotectal projection during chick development. Science 215:1418-1420.

McLoon SC (1985) Evidence for shifting connections during development of the chick retinotectal projection. J Neurosci 5:2570-2580.

McLoon SC, Lund RD (1982) Transient retinofugal pathways in the developing chick. Exp Brain Res 45:277-284.

Nakamura H, O'Leary DDM (1989) Inaccuracies in initial growth and arborization of chick retinotectal axons followed by course corrections and axon, remodeling to develop topographic order. J Neurosci 9: 3776-3795.

O'Leary DDM, Cowan WM (1982) Further studies on the development of the isthmo-optic nucleus with special reference to the occurrence and fate of cetopic and ipsilaterally projecting neurons. $J$ Comp Neurol 212:399-416.

O'Leary DDM, Stanfield BB, Cowan WM (1981) Evidence that the early postnatal restriction of the cells of origin of the callosal projection is due to elimination of axonal collaterals rather than to the death of neurons. Dev Brain Res 1:607-617.

O'Leary DDM, Gerfen CR, Cowan WM (1983) The development and restriction of the ipsilateral retinofugal projection in the chick. Dev Brain Res 10:93-109.

O'Leary DDM, Fawcett JW, Cowan WM (1986) Topographic targeting errors in the retinocollicular projection and their elimination by selective ganglion cell death. J Neurosci 6:3692-3705.

Perry VH, Henderson Z, Linden R (1983) Postnatal changes in retinal ganglion cell and optic axon populations in the pigmented rat. J Comp Ncurol 219:356-368.

Raffin J-P, Reperant J (1975) Etude experimentale de la specificite des projections visuelles d'embryons et de poussins de Gallus domesticus L. microphtalmes et monophtalmes. Arch Anat Microsc 64: 93-111.

Rager G, Rager U (1978) Systems-matching by degeneration. I. A quantitative electron microscopic study of the generation and degeneration of retinal ganglion cells in the chicken. Brain Res 33:65-78.

Schmued LC, Swanson LW, Sawchenko PE (1982) Some fluorescent counterstains for neuroanatomical studies. J Histochem Cytochem 30:123-128.

Sretavan DW (1990) Specific routing of retinal ganglion cell axons at the mammalian optic chiasm during embryonic development. J Neurosci 10:1995-2007.

Thanos S, Bonhoeffer F (1984) Development of the transicnt ipsilateral retinotectal projections in mono-ophthalmic chick embryos. Neurosci microscopic analysis. J Comp Neurol 224:407-414.

Thanos S, Bonhoeffer F (1987) Axonal arborization in the developing chick retinotectal system. J Comp Neurol 261:155-164.

Thanos S, Fujisawa H, Bonhoeffer F (1984) Elimination of ipsilateral retinotectal projections in mono-ophthalmic chick embryos. Neurosci Lett 44:143-148.

Thompson ID (1979) Changes in the uncrossed retinotectal projection after removal of the other eye at birth. Nature 279:63-66.

Weidner C, Reperant J, Miceli D, Haby M, Rio JP (1985) An anatomical study of ipsilateral retinal projections in the quail using radioautographic, horseradish peroxidase, fluorescence and degeneration techniques. Brain Res 340:99-108.

Williams RW, Bastiani MJ, Lia B, Chapula LM (1986) Growth concs, dying axons, and developmental fluctuations in the fiber population of the cat's optic nerve. J Comp Neurol 246:32-69. 